\title{
PENGARUH MODEL PEMECAHAN MASALAH POLYA BERBANTUAN LKPD TERHADAP KEMAMPUAN MENGANALISIS MATERI FISIKA PESERTA DIDIK SMAN 1 SELONG TAHUN PELAJARAN 2016/2017
}

\author{
Masruhin Nur, Hairunnisyah Sahidu, Kosim \\ Program StudiPendidikanFisikaFKIP \\ UniversitasMataram \\ E-Mail: nur.masruhin@gmail.com
}

\begin{abstract}
This study aims to determine the effect of problem solving Polya model assisted by LKPD on the ability to analyze the physics of students. Type of this research is quasi experimental with research design untreated control group design with pre-test and post-test. The population is all students of class $X$. Samples are taken by using purposive sampling technique, so that the class $X$ of MS 1 as experiment class and class X MS 2 as the control class. The analytical ability is measured by a written test in the form of a description. Based on the research result, the average value of the ability to analyze the experimental class students is 60,16 while the mean of the ability to analyze the control class is 41,53. The data capability of analyzing both classes is normally distributed and both homogeneous. Based on the test of hypothesis test-t polled variance, obtained $t_{\text {count }}$ of 3.681. The $t_{\text {table }}$ value for the data analysis ability of 1.996, at a significant level of 5\%. The value of $t_{\text {count }}$ is greater than table, meaning that there is influence of problem solving Ploya model with LKPD help on the ability of analyzing the physics of the students.
\end{abstract}

Keywords : Problem Solving Polya Model, LKPD, Ability to Analyze

\section{PENDAHULUAN}

Perubahan kurikulum dari Kurikulum Tingkat Satuan Pendidikan (KTSP) ke Kurikulum 2013 (K-13) dibuat dalam rangka untuk mempersiapkan peserta didik agar siap menghadapi masa depan. Proses pembelajaran pada kurikulum 2013 diselenggarakan secara interaktif, inspiratif, menyenangkan, menantang, memotivasi peserta didik untuk berpartisipasi aktif, serta memberikan ruang yang cukup bagi prakarsa, kreativitas dan kemandirian sesuai dengan bakat, minat, dan perkembangan fisik serta psikologis peserta didik. Sejak diberlakukannya kurikulum 2013, kemampuan menganalisis mulai banyak dituntut pada kegiatan pembelajaran di seluruh jenjang pendidikan. Berbagai mata pelajaran menuntut peserta didik memiliki kemampuan analisis yang baik. Hal ini agar peserta didik mampu menganalisis informasi atau data yang diperoleh untuk kemudian dikaitkan dan digunakan dalam kehidupan sehari-hari. Salah satu mata pelajaran yang menuntut kemampuan menganalisis yaitu mata pelajaran fisika.

Fisika merupakan bagian dari sains yang memfokuskan kajiannya pada materi, energi, dan hubungan antara keduanya (Gunawan et al, 2015). Proses pembelajaran fisika lebih ditekankan pada pemberian pengalaman langsung untuk mengembangkan kemampuan berpikir peserta didik agar mampu memahami materi fisika dengan baik (Maghfiroh dan Sugianto, 2011). Kemampuan berpikir yang dapat ditumbuhkan pada diri peserta didik saat mempelajari fisika antara lain kemampuan menganalisis yang direfleksikan pada sikap hati-hati dan teliti. Salah satu tujuan dari pembelajaran fisika yaitu peserta didik diharapkan dapat mengkonstruksi pengetahuannya dalam pikirannya dan bekerja memecahkan masalah agar dapat memahami serta menerapkan pengetahuan yang dimiliki 
(Nurqomariah et al, 2015). Namun pada umumnya mata pelajaran fisika justru dikenal sebagai mata pelajaran yang ditakuti dan tidak disukai peserta didik karena dianggap rumit (Purwanto, 2012).

Keberhasilan peserta didik dalam suatu proses pembelajaran dapat ditentukan oleh penggunaan model pembelajaran yang tepat. Seorang guru harus mampu memilih dan menggunakan berbagai model pembelajaran, media yang tepat serta menciptakan iklim pembelajaran yang kondusif sehingga kriteria ketuntasan minimal yang telah ditetapkan tercapai (Jiniarti et al, 2015).Suatu model pembelajaran tentu didukung oleh pendekatan dan metode tertentu sesuai dengan tujuan pembelajaran yang ingin dicapai. Pendekatan yang dimaksud yaitu strategi dalam perencanaan pembelajaran sedangkan metode lebih menekankan pada teknik pelaksanaannya. Namun kenyataan yang dihadapi dunia pendidikan di Indonesia saat ini adalah lemahnya proses pembelajaran (Ekasari et al, 2016).

Proses pembelajaran di dalam kelas lebih banyak diarahkan pada kemampuan peserta didik untuk mengingat dan memahami informasi tanpa dituntut untuk menganalisis dan menghubungkannya dengan kehidupan sehari-hari. Akibatnya, kemampuan peserta didik dalam kategori berpikir tingkat tinggi masih rendah, aktivitas belajar peserta didik juga rendah, sehingga kemampuan analisis peserta didik tidak berkembang. Kemampuan berpikir tingkat tinggi yang dimaksud adalah proses berpikir yang tidak sekedar menghafal dan menyampaikan kembali informasi yang diketahui, tetapi kemampuan menghubungkan,, memanipulasi, dan mentransformasi pengetahuan serta pengalaman yang sudah dimiliki (Rofiah et al, 2013). Tujuan pendidikan menurut Winarti (2015) yang diklasifikasikan dalam menganalisis mencakup belajar menentukan potongan informasi yang relevan dan penting (membedakan), menentukan cara menata potongan informasi tersebut (mengorganisasikan) dan menentukan tujuan dibalik informasi tersebut (mengatribusikan).

Berdasarkan hasil observasi peneliti di sekolah, pemilihan model pembelajaran oleh guru belum terstruktur. Kegiatan pembelajaran di kelas masih didominasi oleh metode ceramah yang menyebabkan aktivitas peserta didik cenderung pasif. Pemilihan model maupun metode ini tentunya akan berpengaruh terhadap hasil belajar fisika peserta didik. Hasil wawancara dengan guru menyatakan bahwa masih banyak peserta didik di dalam satu kelas belum memenuhi KKM, hal ini disebabkan oleh kebiasaan peserta didik ketika dihadapkan dengan soal-soal hitungan tidak bisa menyelesaikannya dengan baik. Peserta didik memiliki kemampuan menganalisis yang masih tergolong rendah, kesulitan dalam memahami masalah, serta kurang memahami konsep fisika terkait.

Konsep fisika akan mudah dipahami dan dikuasai oleh peserta didik jika guru menggunakan model pembelajaran yang efektif serta proses pembelajaran bersifat student centered. Pembelajaran yang efektif akan terjadi jika peserta didik terlibat aktif dalam menemukan pemecahan masalah dari permasalahan yang disajikan selama proses pembelajaran. Pemecahan masalah dipandang sebagai sebuah proses dengan sejumlah aturan yang dikombinasikan dalam upaya untuk mengatasi situasi yang baru (Wena, 2014). Aturan yang dimaksud akan disediakan dan diajarkan oleh guru sedangkan peserta didik harus mempelajari aturan tersebut. Pemecahan masalah juga merupakan bagian dari kurikulum fisika yang sangat penting karena dalam proses pembelajaran maupun penyelesaiannya, peserta didik dimungkinkan memperoleh pengalaman menggunakan pengetahuan serta keterampilan 
yang sudah dimiliki untuk diterapkan padapemecahan masalah (Venisari et al, 2015). Pembelajaran dengan menggunakan model pemecahan masalah menitik beratkan agar peserta didik mampu mengutarakan tujuan, menganalisa data, mengemukakan pendapat dan memberi keputusan ketika menghadapi suatu permasalahan di dalam proses pembelajaran.Salah satu model pembelajaran yang mampu melibatkan peserta didik aktif dalam memecahkan masalah adalah model pemecahan masalah Polya.

Model pemecahan masalah Polya adalah pola kegiatan belajar yang dikombinasikan dengan rencana untuk memperoleh pemecahan masalah melalui empat tahap yaitu (1) memahami masalah, (2) menyusun rencana penyelesaian masalah, (3) menjalankan rencana, dan (4) mengecek kembali penyelesaian masalah. Penelitian terkait dengan model pemecahan masalah Polya oleh Hadi dan Radiyatul (2014) menyatakan bahwa model pemecahan masalah polya merupakan upaya mencari jalan keluar (solusi) yang dimulai dengan pemberian masalah sampai dengan menarik kesimpulan yang memerlukan kreativitas dan pengetahuan peserta didik. Penelitian oleh Komariah (2011) bahwa pemecahan masalah model Polya dapat meningkatkan kemampuan peserta didik dalam memecahkan masalah matematika.

Kompetensi Dasar (KD) pada mata pelajaran fisika tingkat SMA mengembangkan aspek kemampuan menganalisis yang tentunya berguna untuk menunjang kemampuan bernalar dalam berpikir analisis dengan menggunakan konsep dan prinsip fisika untuk menjelaskan berbagai peristiwa alam dan penyelesaian masalah baik secara kualitatif maupun kuantitatif. Oleh karena itu, dibutuhkan perangkat pembelajaran yang dapat diinovasikan untuk melatih kemampuan berpikir analisis peserta didik. Salah satu perangkat pembelajaran yang dapat dikembangkan atau diinovasikan yakni Lembar Kerja Peserta Didik (LKPD). Fitriyati, et al (2013) menyatakan bahwa LKPD termasuk media pembelajaran cetak yang dapat digunakan untuk menciptakan proses pembelajaran yang efektif dan efisien. Dengan adanya LKPD, maka proses pembelajaran di kelas akan menjadi lebih efektif dan efisien.

Jenis LKPD yang biasa digunakan di tempat melaksanakan penelitian adalah LKPD untuk melakukan eksperimen dan LKPD berisi soal-soal. Jika ditinjau lebih jauh, LKPD merupakan salah satu perangkat pembelajaran yang dapat disajikan dengan berbagai inovasi dan kreativitas yang dimiliki oleh guru untuk memfasilitasi kegiatan pembelajaran. Guru dapat memadukan atau mengembangkan LKPD dengan model-model pembelajaran yang sesuai dengan kebutuhan peserta didik. Penelitian terkait yang dilakukan oleh Nurliawaty, et al (2017) bahwa LKPD berbasis pemecahan masalah Polya memberikan efek yang positif terhadap pembelajaran di kelas yang dibuktikan dengan meningkatnya kemampuan menganalisis peserta didik.

Keberhasilan penelitian di atas, memotivasi peneliti untuk memadukan LKPD dengan model pemecahan masalah Polya. LKPD ini dirancang secara sistematis sesuai tahap-tahap dalam model pemecahan masalah Polya yakni (1) memahami masalah, (2) menyusun rencana penyelesaian masalah, (3) menjalankan rencana dan (4) mengecek kembali penyelesaian masalah yang telah dijalankan.

\section{METODE PENELITIAN}

Penelitian kuasi eksperimen ini menggunakan untreated control group design with pretest and posttest. Sebelum diberi perlakuan kedua kelas diberikan tes awal untuk mengetahui kemampuan awal peserta didik. 
Selanjutnya kelas eksperimen diberikan perlakuan berupa model pemecahan masalah Polya berbantuan LKPD dan kelas control diberi perlakuan berupa model pembelajaran langsung (direct instruction). Sesudah diberikan perlakuan, kedua kelas di berikan tes akhir untuk mengetahui pengaruh dari perlakuan yang diberikan. Penelitian ini melibatkan variabel bebas yaitu model pemecahan masalah Polya berbantuan LKPD, variabel terikat yaitu kemampuan menganalisis materi fisika, dan variabel kontrol yaitu waktu, guru yang mengajar dan materi ajar.

Penelitian ini dilakukan di SMA Negeri 1 Selong. Populasinyaseluruh kelas $X$ yang ada di SMAN 1 Selong. Sampel penelitian 76 peserta didik yang dibagi dalam dua kelas yakni 38 peserta didik sebagai kelas eksperimen dan 38 peserta didik sebagai kelas kontrol. Pemilihan sampel menggunakan teknik Purposive sampling. Purposive sampling adalah teknik penentuan sampel dengan pertimbangan tertentu (Sugiyono, 2015). Instrumen yang digunakan adalah tes kemampuan menganalisis dengan teknik pengumpulan data berupa tes tertulis berbentuk soal uraian. Tes kemampuan menganalisis berjumlah 11 soal. Indikator yang digunakan dalam kemampuan menganalisis ini adalah (1) membedakan yaitu kemampuan memilih atau memfokuskan untuk menentukan bagian penting dan tidak penting dalam suatu materi; (2) mengorganisasi yaitu kemampuan mengidentifikasi suatu elemen yang menyusun dan menghubungjkan suatu materi; dan (3) mengatribusi yaitu kemampuan untuk menentukan sudut pandang dalam membuat kesimpulan dari suatu materi (Anderson \& Kratwohl, 2010). Instrumen tes kemampuan menganalisis sebelum digunakan harus memenuhi beberapa syarat yaitu uji validitas dan reliabilitas.

\section{HASIL DAN PEMBAHASAN}

Hasil penelitian berupa deskripsi hasil tes awal dan tes akhir dengan menggunakan uji normalitas, uji homogenitas dan uji hipotesis.

Penelitian ini bertujuan untuk mengetahui pengaruh model pemecahan masalah Polya berbantuan LKPD terhadap kemampuan menganalisis materi fisika peserta didik. Kemampuan menganalisis yang dimaksud adalah suatu proses memilah dan menguraikan materi menjadi bagian-bagian kecil yang lebih jelas (membedakan), kemudian mencari hubungan (mengorganisasi) setiap bagian tersebut, sehingga diperoleh pemecahan masalah sebagai dasar untuk menarik kesimpulan tujuan dan sudut pandang permasalahan (mengatribusi). Tes kemampuan menganalisis diberikan sebelum dan sesudah perlakuan melalui tes awal dan tes akhir.

Sebelum instrumen tes awal diberikan pada kelas eksperimen dan kontrol, peneliti terlebih dahulu melakukan validasi empiris dengan uji coba instrumen di kelas XI MS 6 yang telah mempelajari materi usaha dan energi sebanyak 15 soal. Kemudian hasilnya diuji validitas dan reliabilitasnya. Berdasarkan hasil uji validitas dan reliabilitas dari 15 soal, semuanya reliabel tetapi hanya 11 soal tes saja yang valid. Selain melakukan validasi empiris, dilakukan juga validasi ahli oleh dosen pembimbing I dan II, yaitu LKPD, RPP, soal tes kemampuan menganalisis, dan kisi-kisi soal yang meliputi validasi isi, konstruksi, dan bahasa.

Analisis data yang dilakukan berdasarkan tes awal dan tes akhir, menunjukkan bahwa terdapat peningkatan kemampuan menganalisis pada kedua kelas. Nilai tes awal peserta didik pada kedua kelas sama-sama rendah, hal ini disebabkan karena peserta didik belum menerima pembelajaran tentang materi usaha dan energi. Selanjutnya setelah diberikan perlakuan nilai yang diperoleh kedua kelas 
mengalami peningkatan, namun terdapat perbedaan antara kemampuan menganalisis peserta didik yang proses pembelajarannya menggunakan model pemecahan masalah Polya berbantuan LKPD dengan proses pembelajarannya menggunakan model pembelajaran langsung. Hasil tes awal dan tes akhir kedua kelas dapat dilihat pada Tabel 1 berikut.

Tabel 1. Skor Rata-rata Kedua Kelas

\begin{tabular}{ccc}
\hline \multicolumn{1}{c}{ Kelas } & Kemampuan & Rata-rata \\
\hline \multirow{2}{*}{ Eksperimen } & Awal & 24,89 \\
& Akhir & 60,16 \\
\multirow{2}{*}{ Kontrol } & Awal & 25,14 \\
& Akhir & 41,53 \\
\hline
\end{tabular}

Data pada Tabel 1 diperlihatkan bahwa nilai rata-rata tes awal kelas kontrol lebih besar yaitu 25,14, sedangkan nilai rata-rata kelas eksperimen sebesar 24,89. Setelah kedua kelas diberi perlakuan, kemampuan menganalisis materi fisika peserta didik pada tes akhir untuk kelas eksperimen meningkat menjadi 60,16 lebih tinggi daripada kelas kontrol dengan nilai rata-rata 41,53. Nilai rata-rata tes akhir menunjukkan bahwa kemampuan menganalisis materi fisika kelas eksperimen dan kelas kontrol sama-sama mengalami peningkatan. Kelas eksperimen mengalami peningkatan nilai rata-rata sebesar 35,27, sedangkan kelas kontrol mengalami peningkatan sebesar 16,39. Hasil tersebut menunjukkan bahwa peningkatan nilai rata-rata kelas eksperimen lebih baik dari kelas kontrol seperti yang diperlihatkan pada Gambar 1. Artinya, terdapat pengaruh positif dari penerapan model pemecahan masalah Polya berbantuan LKPD pada kelas eksperimen.

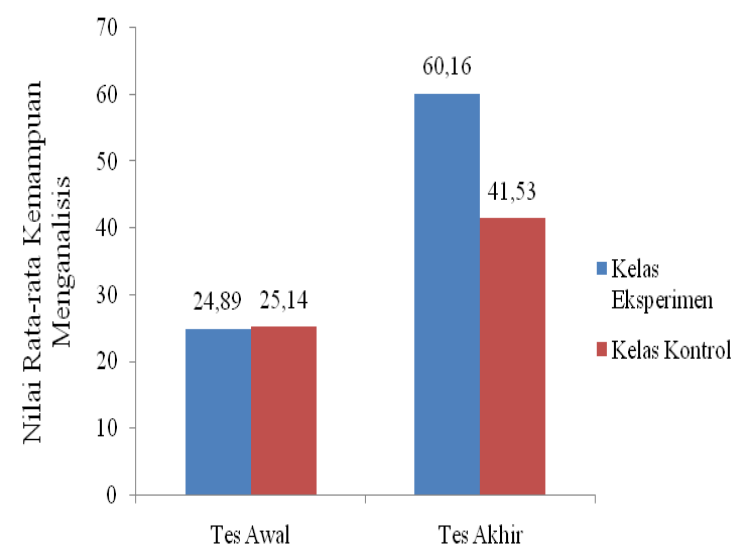

Gambar 1. Kemampuan Menganalisis Materi Fisika Kelas Eksperimen dan Kontrol

Berdasarkan hasil perhitungan tes awal dan tes akhir kemampuan menganalisis materi fisika peserta didik pada tiap-tiap indikator, didapatkan persentase kemampuan menganalisis seperti ditunjukkan pada Tabel 2 berikut.

Tabel 2. Kemampuan Menganalisis Peserta Didik Kelas Eksperimen dan kelas Kontrol (\%)

\begin{tabular}{ccccc}
\hline \multirow{2}{*}{ Kelas } & \multirow{2}{*}{ Tes } & \multicolumn{3}{c}{ Indikator Kemampuan Menganalisis (\%) } \\
& & Membedakan & Mengorganisasi & Mengatribusi \\
\hline Eksperimen & \multirow{2}{*}{ Awal } & 29,4 & 10,1 & 35,9 \\
Kontrol & & 27,1 & 3,3 & 43,9 \\
Eksperimen & \multirow{2}{*}{ Akhir } & 60,4 & 49,7 & 69,7 \\
Kontrol & \multirow{2}{*}{54,1} & 7,7 & 64,1 \\
\hline
\end{tabular}

Data pada Tabel 2 menunjukkan hasil persentase nilai rata-rata kemampuan menganalisis materi fisika peserta didik pada tes awal dan tes akhir. Persentase nilai rata-rata tes awal yang diperoleh sampel kelas eksperimen pada indikator membedakan sebesar 29,4\%, mengorganisasi $10,1 \%$ dan mengatribusi $35,9 \%$. Sedangkan persentase nilai rata-rata tes awal yang diperoleh sampel kelas kontrol pada indikator membedakan sebesar $27,1 \%$, mengorganisasi 3,3\%, dan mengatribusi $43,9 \%$. 
Selanjutnya, persentase nilai rata-rata tes akhir kemampuan menganalisis materi fisika oleh sampel kelas eksperimen pada indikator membedakan sebesar 60,4\%, mengorganisasi $49,7 \%$, dan mengatribusi 64,1\%. Dan persentase nilai rata-rata tes akhir kemampuan menganalisis materi fisika oleh sampel kelas kontrol pada indikator membedakan sebesar $54,1 \%$, mengorganisasi $7,7 \%$, dan mengatribusi $64,1 \%$. Untuk lebih jelasnya, perolehan persentase hasil tes awal dan tes akhir pada masing-masing indikator kemampuan menganalisis materi fisika peserta didik ditunjukkan oleh gambar 2 dan gambar 3 berikut.

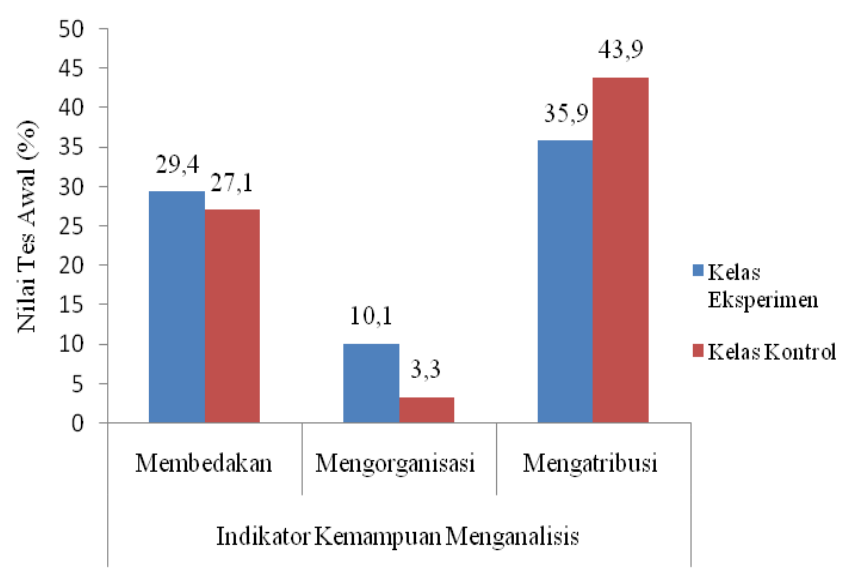

Gambar 2. Hasil Tes Awal Kemampuan Menganalisis Materi Fisika Kelas Eksperimen dan Kontrol

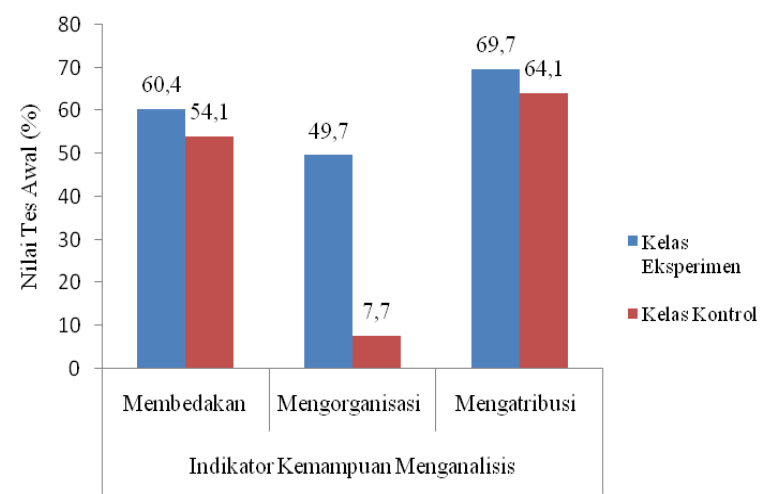

Gambar 3. Hasil Tes Akhir Kemampuan Menganalisis Materi Fisika Kelas Eksperimen dan Kontrol

Berdasarkan gambar 2 terlihat bahwa kemampuan menganalisis materi fisika peserta didik kelas kontrol pada indikator mengatribusi lebih unggul daripada kelas eksperimen, sedangkan indikator membedakan dan mengorganisasi kelas eksperimen lebih unggul daripada kelas kontrol. Secara umum gambar 2 dan 3 memperlihatkan bahwa terjadi peningkatan nilai kemampuan menganalisis dari tes awal hingga tes akhir, walaupun terdapat indikator yang masih tergolong sangat rendah. Peningkatan kemampuan menganalisis materi fisika pada kelas eksperimen lebih tinggi dibandingkan dengan kelas kontrol, hal ini menunjukkan bahwa model pemecahan masalah Polya berbantuan LKPD lebih mampu meningkatkan kemampuan menganalisis materi fisika peserta didik pada kelas eksperimen dibandingkan pembelajaran langsung pada kelas kontrol.

Pengujian data diawali dengan pengujian homogenitas data dan normalitas data tes awal dan tes akhir. Tujuannya adalah untuk menentukan jenis uji hipotesis yang akan digunakan. Uji homogenitas sebaran data menggunakan uji-F sedangkan untuk uji normalitas digunakan persamaan Chi-Kuadrat. Berdasarkan data tes awal yang diperoleh pada kelas eksperimen dan kelas kontrol, didapatkan bahwa $F_{\text {hitung }}<F_{\text {tabel }}$, maka kedua sampel dikatakan homogen. Pada tes akhir juga terlihat bahwa $F_{\text {hitung }}<F_{\text {tabel }}$, sehingga kedua sampel dikatakan homogen. Selanjutnya dilakukan uji normalitas data tes awal dan tes akhir pada masing-masing kelas. Berdasarkan perhitungan yang telah dilakukan diperoleh hasil bahwa $\chi_{\text {hitung }}^{2}<\chi_{\text {tabel }}^{2}$ artinya bahwa sebaran data terdistribusi normal pada tes awal dan tes akhir baik kelas eksperimen maupun kelas kontrol. Hasil ini menunjukkan bahwa uji hipotesis yang digunakan adalah dengan persamaan parametrik yang dalam hal ini menggunakan uji-t.

Selanjutnya digunakan uji-t polled varians karena sampel pada penelitian ini 
berbeda $\left(n_{1} \neq n_{2}\right)$. Berdasarkan uji statistik yang dilakukan didapatkan nilai $t_{\text {hitung }}$ lebih besar dari $t_{\text {tabel }}$ pada taraf signifikan $5 \%$. Berdasarkan kriteria bahwa jika $t_{\text {hitung }}>$

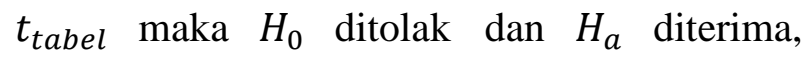
sehingga hasil uji tersebut menunjukkan adanya pengaruh model pemecahan masalah Polya berbantuan LKPD terhadap kemampuan menganalisis materi fisika peserta didik.

Berdasarkan hasil uji N-Gain antara kelas eskperimen dan kelas kontrol yang dianalisis pada setiap indikator kemampuan menganalisis, menunjukkan terjadi peningkatan yang baik pada kelas eksperimen. Perolehan uji N-gain kelas eksperimen pada indikator membedakan, mengorganisasi dan mengatribusi tergolong sedang dengan persentase berturut-turut sebesar 40\%, 40\% dan $50 \%$. Sementara itu kelas kontrol memperoleh kategori sedang pada indikator membedakan dan mengatribusi saja dengan persentase $30 \%$ dan 40\%, sedang pada indikator mengorganisasi memperoleh kategori rendah dengan persentase $5 \%$.

Hasil penelitian menggambarkan bahwa kemampuan menganalisis materi fisika peserta didik mengalami peningkatan pada kedua kelas, namun peningkatan pada kelas eksperimen lebih baik daripada kelas kontrol. Hal tersebut terjadi karena pembelajaran menggunakan model pemecahan masalah Polya memudahkan peserta didik dalam menemukan penyelesaian dari suatu permasalahan melalui empat langkah pemecahan masalah yang di susun secara sistematis. Komariah (2011) menyatakan bahwa pemecahan masalah model Polya dapat meningkatkan kemampuan peserta didik dalam memecahkan masalah matematika.

Pada model pemecahan masalah Polya berbantuan LKPD, peneliti memberikan LKPD untuk mengasah kemampuan menganalisis peserta didik dengan memberikan contoh soal dilengkapi penyelesaiannya berdasarkan langkah pemecahan masalah Polya, serta memberikan soal-soal latihan untuk menciptakan diskusi kelompok agar peserta didik aktif dalam bekerja sama dengan kelompok. Ketika pembelajaran berlangsung, peserta didik terlihat cukup antusias.

Model pembelajaran yang diterapkan dapat membantu peserta didik menjadi lebih aktif. Peserta didik diminta untuk belajar memahami dan menyelesaikan permasalahan fisika dengan langkah-langkah pemecahan masalah yang telah disajikan dalam LKPD. Pembelajaran di dalam kelas tidak cukup hanya dengan menerapkan model karena suatu model pembelajaran perlu dilengkapi dengan media atau perangkat pembelajaran untuk membantu peserta didik lebih memahami apa yang dipelajari pada proses pembelajaran.

Pada saat pembelajaran, peserta didik kelas eksperimen lebih aktif bertanya ataupun berdiskusi dibandingkan dengan kelas kontrol. Peserta didik pada kelas eksperimen cukup antusias dengan adanya LKPD yang diberikan. Sedangkan pada kelas kontrol tidak menunjukkan hal demikian karena saat pembelajaran berlangsung hanya diberikan lembar kerja yang berisi soal-soal tanpa ringkasan materi, dan contoh soal serta penyelesaiannya. Akibatnya, nilai rata-rata kemampuan menganalisis pada kelas eksperimen dengan model pemecahan masalah Polya berbantuan LKPD lebih tinggi daripada kelas kontrol dengan model pembelajaran langsung. Hal ini menunjukkan bahwa kelas eksperimen lebih baik dibandingkan kelas kontrol.

Menurut Aji \& Widodo (2017), lembar kerja peserta didik (LKPD) berfungsi sebagai penuntun siswa untuk menyelesaikan suatu masalah dalam pembelajaran. Manfaat LKPD lebih lanjut dijelaskan oleh Suyitno (dalam Aji et. al., 2017). Adapun maanfaatnya adalah 
sebagai berikut. (1) mengaktifkan peserta didik dalam proses pembelajaran; (2) Membantu peserta didik dalam mengembangkan konsep; (3) Melatih peserta didik dalam menemukan dan mengembangkan keterampilan proses; (4) sebagai pedoman guru dan peserta didik dalam melaksanakan proses pembelajaran;

Membantu peserta didik memperoleh catatan tentang materi yang dipelajari melalui kegiatan belajar; (6) Membantu peserta didik untuk menambah informasi tentang konsep yang dipelajari melalui belajar sistematis.

Hasil penelitian yang sudah dilakukan menggambarkan bahwa kemampuan menganalisis materi fisika yang dimiliki peserta didik berbeda dengan kemampuan awalnya. Kelas eksperimen maupun kelas kontrol mengalami peningkatan, namun peningkatan kelas eksperimen lebih baik daripada kelas kontrol. Hal ini disebabkan oleh penerapan model pemecahan masalah Polya berbantuan LKPD pada kelas eksperimen. Berdasarkan analisis data hasil penelitian bahwa model pemecahan masalah Polya berbantuan LKPD pada pembelajaran usaha dan energi dapat meningkatkan kemampuan menganalisis materi fisika peserta didik.

Temuan dalam penelitian ini memperkuat beberapa penelitian sebelumnya salah satu diantaranya adalah penelitian yang dilakukan oleh Ikhwanuddin, et. al., (2010) dan disimpulkan bahwa model pemecahan masalah dirasa cukup tepat untuk meningkatkan kemampuan berpikir analisis, karena melalui metode ini diberikan prosedur pemecahan masalah dengan berbagai pendekatan atau model.

\section{PENUTUP}

Berdasarkan hasil penelitian yang telah dilaksanakan dapat disimpulkan bahwa terdapat pengaruh model pemecahan masalah Polya berbantuan LKPD terhadap kemampuan menganalisis materi fisika peserta didik. Kelas eksperimen dan kelas kontrol mengalami peningkatan kemampuan menganalisis pada semua indikator yani membedakan, mengorganisasi dan mengatribusi. Peningkatan kemampuan menganalisis kelas eksperimen lebih baik dibandingkan kelas kontrol. Perhitungan persentase hasil kemampuan menganalisis menunjukkan bahwa persentase tertinggi terjadi pada indikator membedakan, dan persentase terendah terjadi pada indikator mengorganisasi. Secara umum kemampuan menganalisis materi fiska peserta didik pada kelas eksperimen lebih tinggi dibandingkan kelas kontrol. Adapun saran yang dapatdiberikanbagi guru fisika yaitu pembelajaran dengan model pemecahan masalah Polya berbantuan LKPD dapat diterapkan dalam mengajar fisika. Adapun dalam penerapannya memerlukan perencanaan dan persiapan yang matang sebelum diterapkan dikelas agar proses pembelajaran dapat berjalan sesuai dengan tujuan pembelajaran yang hendak dicapai. Sedangkan untuk penelitian selanjutnya, model pemecahan masalah Polya berbantuan LKPD dapat dilakukan pada materi pokok yang lain dengan jumlah sampel yang lebih besar sehingga bisa didapatkan hasil yang lebih akurat dan membahas lebih mendalam pada bagian yang lain.

\section{REFERENSI}

Anderson \& Krathwol. 2010. Kerangka Landasan untuk Pembelajaran Pengajaran dan Asesmen Revisi Taksonomi Pendidikan Bloom (terjemahan). Jakarta: Pustaka Belajar.

Aji, N.S. \& Widodo. 2017. Pengembangan LKS Gerak Harmonik Sederhana dengan Media virtual laboratory Berbasis Problem Based Instruction. Jurnal Penelitian Pembelajaran Fisika. 8(1) 4450. 
Ekasari, R. R., Gunawan, G., Sahidu, H. 2016. Pengaruh Model Pembelajaran Langsung Berbantuan Media Laboratorium terhadap Kreatifitas Fisika Siswa SMA. Jurnal Pendidikan Fisika dan Teknologi, 1(3), 106-107.

Fitriyati, Kurniawan, E. S., \& Ngazizah, N. (2013). Pengembangan LKS Fisika SMA Kelas X Semester II dengan Website Online Berbasis Contextual Teaching Learning. Jurnal Pendidikan Fisika Radiasi, 3(1), 7-11.

Hadi, S., Radiyatul. 2014. Metode Pemecahan Masalah Menurut Polya untuk Mengembangkan Kemampuan Siswa dalam Pemecahan Masalah Matematis. Jurnal Pendidikan Matematika, 2(1), 5361.

Gunawan, G., Harjono, A., \& Sahidu, H. 2015. Studi Pendahuluan pada Upaya Pengembangan Laboratorium Virtual bagi Calon Guru Fisika. Jurnal Pendidikan Fisika dan Teknologi, 1(2), 140-145.

Ikhwanuddin, Jaedun, A.,\& Purwantoro, D. 2010. Problem Solving dalam Pembelajaran Fisika untuk Meningkatkan Kemampuan Mahasiswa Berpikir Analitis. Jurnal Kependidikan, 40(2), 215-230.

Jiniarti, B. E., Sahidu, H.,\& Verawati, S. P. 2015. Implementasi Model Problem Based Learning berbantuan Alat Peraga untuk Meningkatkan Aktivitas dan Hasil Belajar Fisika Siswa Kelas VIII SMPN 22 Mataram Tahun Pelajaran 2014/2015. Jurnal Pendidikan Fisika dan Teknologi, 1(3), 185-192.

Komariah, K. 2011. Penerapan Metode Pembelajaran Problem Solving Model Polya untuk Meningkatkan Kemampuan Memecahkan Masalah Bagi Siswa Kelas IX J di SMPN 3 Cimahi. Prosiding Seminar Nasional Penelitian, Pendidikan dan Penerapan MIPA Fakultas MIPA UN, 181-217.
Maghfiroh, U., Sugianto. 2011. Penerapan Pembelajaran Fisika Bervisi Sets untuk Meningkatkan Kemampuan Berpikir Analitis Peserta Didik Kelas X. Jurnal Pendidikan Indonesia, 6-12.

Nurliawaty, L., Mujasam, Yusuf, I., \& Widyaningsih, SW. 2017. Pengembangan Lembar Kerja Peserta Didik (LKPD) berbasis pemecahan masalah Polya pada Materi Kalor. Jurnal Pendidikan Indonesia, 6(1), 72-81.

Nurqomariah, Gunawan, \&Sutrio. 2015. Pengaruh Model Problem Based Learning dengan Metode Eksperimen terhadap Hasil Belajar IPA Fisika Siswa Kelas VII SMP Negeri 19 Mataram Tahun Pelajaran 2014/2015. Jurnal Pendidikan Fisika dan Teknologi, 1(3), 173-178.

Purwanto, A. 2012. Kemampuan Berpikir Logis Siswa SMA Negeri 8 Kota Bengkulu dengan Meneerapkan Model Inkuiri Terbimbing dalam Pembelejaran Fisika. Jurnal Exacta, 10(2), 133-135.

Rofiah, E., Aminah, N. S., \& Ekawati, E. Y. 2013. Penyusunan Instrumen Tes Kemampuan Berpikir Tingkat Tinggi Fisika pada Siswa SMP. Jurnal Pendidikan Fisika, 1(2), 17-22.

Sugiyono. 2015. Statistika untuk Penelitian. Bandung: Alfabeta.

Venisari, R., Gunawan,\& Sutrio. 2015. Penerapan Metode Mind Mapping pada Model Direct Instruction untuk Meningkatkan Kemampuan Pemecahan Masalah Fisika Siswa SMPN 16 Mataram. Jurnal Pendidikan Fisika dan Teknologi, 1(3), 193-198.

Wena, M. 2014. Strategi Pembelajaran Inovatif Kontemporer Suatu Tinjauan Konseptual Operasional. Jakarta: Bumi Aksara.

Winarti. 2015. Profil Kemampuan Berpikir Analisis dan Evaluasi Mahasiswa dalam Mengerjakan Soal Konsep Kalor. Jurnal Inovasi dan Pembelajaran Fisika, 2(1), 19-24. 